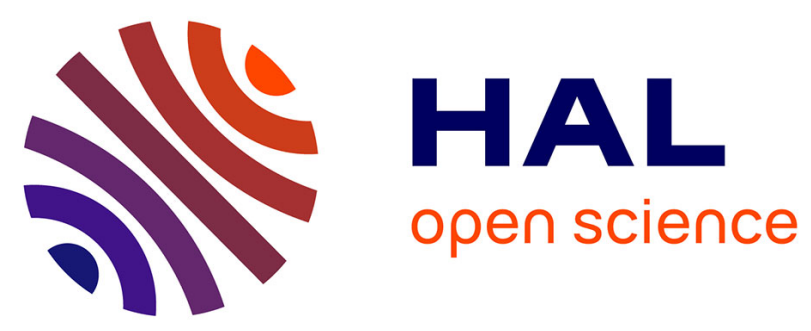

\title{
Preliminary data from Valle Giumentina Pleistocene site (Abruzzo, Central Italy): A new approach to a Clactonian and Acheulian sequence
}

Elisa Nicoud, Daniele Aureli, Marina Pagli, Valentina Villa, Christine Chaussé, Silvano Agostini, Jean-Jacques Bahain, Giovanni Boschian, Jean-Philippe Degeai, Fabio Fusco, et al.

\section{To cite this version:}

Elisa Nicoud, Daniele Aureli, Marina Pagli, Valentina Villa, Christine Chaussé, et al.. Preliminary data from Valle Giumentina Pleistocene site (Abruzzo, Central Italy): A new approach to a Clactonian and Acheulian sequence. Quaternary International, 2016, 409, pp.182 - 194. 10.1016/j.quaint.2015.08.080 . hal-01481268

\section{HAL Id: hal-01481268 https://hal.science/hal-01481268}

Submitted on 9 Dec 2021

HAL is a multi-disciplinary open access archive for the deposit and dissemination of scientific research documents, whether they are published or not. The documents may come from teaching and research institutions in France or abroad, or from public or private research centers.
L'archive ouverte pluridisciplinaire HAL, est destinée au dépôt et à la diffusion de documents scientifiques de niveau recherche, publiés ou non, émanant des établissements d'enseignement et de recherche français ou étrangers, des laboratoires publics ou privés. 


\title{
Preliminary data from Valle Giumentina Pleistocene site (Abruzzo, Central Italy): A new approach to a Clactonian and Acheulian sequence
}

\author{
Elisa Nicoud ${ }^{\mathrm{a},{ }^{*}}$, Daniele Aureli ${ }^{\mathrm{b}, \mathrm{c}}$, Marina Pagli ${ }^{\mathrm{c}}$, Valentina Villa ${ }^{\mathrm{a}, \mathrm{d}}$, \\ Christine Chaussé ${ }^{\mathrm{d}, \mathrm{e}}$, Silvano Agostini ${ }^{\mathrm{f}}$, Jean-Jacques Bahain ${ }^{\mathrm{g}}$, Giovanni Boschian ${ }^{\mathrm{h}}$, \\ Jean-Philippe Degeai ${ }^{i}$, Fabio Fusco ${ }^{j}$, Biagio Giaccio ${ }^{k}$, Marion Hernandez ${ }^{1}$, \\ Catherine Kuzucuoglu ${ }^{\mathrm{d}}$, Christelle Lahaye ${ }^{\mathrm{m}}$, Cristina Lemorini ${ }^{\mathrm{n}}$, \\ Nicole Limondin-Lozouet ${ }^{\mathrm{d}}$, Paul Mazza ${ }^{\mathrm{o}}$, Norbert Mercier ${ }^{\mathrm{m}}$, Sébastien Nomade ${ }^{\mathrm{p}}$, \\ Alison Pereira ${ }^{\mathrm{a}, \mathrm{g}}$, Vincent Robert ${ }^{\mathrm{d}}$, Maria Adelaide Rossi ${ }^{\mathrm{f}}$, Clément Virmoux ${ }^{\mathrm{d}}$, \\ Andrea Zupancich ${ }^{\mathrm{q}}$ \\ a École française de Rome, Piazza Farnese 67, 00186 Roma, Italy \\ ${ }^{\mathrm{b}}$ Università degli Studi di Siena, U.R. Preistoria e Antropologia, Via Laterina 8, 53100 Siena, Italy \\ c UMR 7041 ArScAn-AnTET, 21 allée de l'université, 92023 Nanterre, France \\ ${ }^{\mathrm{d}}$ UMR 8591-CNRS Laboratoire de Géographie Physique, 1 Place Aristide Briand, 92195 Meudon, France \\ e Inrap, 7 rue de Madrid, 75008 Paris, France \\ ${ }^{\mathrm{f}}$ Soprintendenza per $\mathrm{i}$ Beni Archeologici dell'Abruzzo, Via degli Agostiniani 14, 66100 Chieti, Italy \\ ${ }^{g}$ UMR 7194-CNRS, Département de Préhistoire du Muséum national d'Histoire naturelle, 1 rue René Panhard, 75013 Paris, France \\ h Università degli studi di Pisa, Dipartimento di Biologia, via Luca Ghini 13, 56126 Pisa, Italy \\ ${ }^{\text {i } U M R ~ 5140-C N R S, ~ A r c h e ́ o l o g i e ~ d e s ~ s o c i e ́ t e ́ s ~ m e ́ d i t e r r a n e ́ e n n e s, ~} 390$ avenue de Pérols, 34970 Lattes, France \\ ${ }^{\mathrm{j}}$ Viale Giovanni Bovio 10, 65123 Pescara, Italy \\ ${ }^{\mathrm{k}}$ CNR-Istituto di Geologia Ambientale e Geoingegneria, Via salaria km 29,300, 00015 Monterotondo, Rome, Italy \\ ${ }^{1}$ Max Planck Institut for Evolutionary Anthropology, Deutscher Platz 6, 04103 Leipzig, Germany \\ ${ }^{\mathrm{m}}$ UMR 5060-CNRS-Université Bordeaux 3 Institut de Recherche sur les Archéomatériaux, Maison de l'Archéologie, Esplanade des Antilles, 33607 Pessac \\ Cedex, France \\ ${ }^{n}$ Università di Roma La Sapienza, Dipartimento di Scienze dell'Antichità, Museo delle Origini, Piazzale Aldo Moro 5, 00185 Roma, Italy \\ ${ }^{\circ}$ Università degli Studi di Firenze, Dipartimento di Scienze della Terra, Via La Pira 4, 50121 Firenze, Italy \\ p CEA LSCE, F-91191 Gif-sur-Yvette, France \\ ${ }^{\mathrm{q}}$ Tel Aviv University, Department of Archaeology and Near Eastern Cultures, Tel Aviv, Israel
}

\section{A R T I C L E I N F O}

\section{Article history:}

Available online $\mathrm{xxx}$

\section{Keywords:}

Middle Pleistocene

Stratigraphy

Lithic technology

Clactonian

Italy

\begin{abstract}
A B S T R A C T
Valle Giumentina is a Pleistocene open-air site in Central Italy (Abruzzo). Nine archaeological layers occur in the last $25 \mathrm{~m}$ of a $70 \mathrm{~m}$ thick sedimentary sequence. In the 1950s, the various archaeological layers were attributed to the Clactonian, Acheulian and Levalloisian traditions. Recent multidisciplinary fieldwork and studies (2012-2016) acquired new archaeological, chronostratigraphical and paleoenvironmental data. This contribution presents the preliminary results of the ongoing excavation of layer 42ALB. This is a paleosol located at $4 \mathrm{~m}$ depth, at the top of a lacustrine deposit directly below the coarse deposits associated with the last major erosive event. Faunal remains consisted essentially by Cervus elaphus. The lithic series is characterized by a specific flake production system: only a part of the block is reduced, and platforms and surfaces are not prepared. Several methods are used, including the SSDA (système par surfaces de débitage alternées). Backed flakes are frequent. Numerous blanks are transformed by intensive or marginal retouch. Functional objectives are multiple, as shown by different tool structures and use-wear traces. Valle Giumentina 42-ALB is a butchery site used briefly but frequently during warmer substages occurring during an overall cold period. The "Clactonian" industry of Valle Giumentina is often considered as simple or expedient: we demonstrate its real technical complexity and its functional significance. Comparisons are made with other European sites.
\end{abstract}

() 2015 Elsevier Ltd and INQUA. All rights reserved.

\footnotetext{
* Corresponding author.

E-mail address: elisa.nicoud@gmail.com (E. Nicoud).
} 


\section{Introduction}

We present the preliminary archaeological, stratigraphical and paleoenvironmental data recently obtained on the Middle Pleistocene site of Valle Giumentina (Abbateggio, Abruzzo, Italy). Valle Giumentina is an open-air site located east of the Apennines ridge, on the Adriatic side of Italy, on the northwestern slopes of the calcareous Majella massif (Fig. 1). It is now a hanging, terraced and flat valley at $740 \mathrm{~m}$ a.s.l. filled by $70 \mathrm{~m}$ of Quaternary deposits in its centre. A linear incision affects the distal part of the basin, exposing the 25 m-thick upper part of its sedimentary infill. It is partially made of lacustrine deposits and paleosols, including nine well stratified archaeological levels. Thousands of lithic artefacts were discovered during the first excavations in 1953-54 (Demangeot and Radmilli, 1953, 1966). They have been described as Clactonian, Acheulian and Levalloisian and assigned to the Rissian and Würmian. This cultural labelling is also due to the occurrences in some layers of "simple" flake production systems (layers 20, 24, 30, 33 , 40, 42; Fig. 2) while another one reveals a handaxe industry (layer 37). On top of the sequence a mixed industry occurs which includes Levallois products (layer 45, 46; Fig. 2). Aware of the differences between the Valle Giumentina industry and the one from Clacton-on-Sea in England, Radmilli (1999) also used the term "Evolved Clactonian of Valle Giumentina facies".

The Valle Giumentina Clactonian and Acheulian lithic series have been central in the Italian debate on the Lower Palaeolithic despite the absence of any fieldwork since 1954. For many authors the cultural changes within the sequence reinforced the two parallel and distinct phyla hypothesis inherited from Breuil's model (Breuil, 1932; Radmilli, 1965). For others, the presence or absence of handaxe was not a reliable criterion to distinguish Acheulian and Clactonian (Bietti and Castorina, 1992). Whereas the Clactonian group is considered obsolete (Ashton et al., 1994), no technical revision of the Italian Clactonian has been undertaken so far. Moreover in Italy, Clactonian is mainly attested by remains and sites with no stratigraphical setting (Grifoni and Tozzi, 2006). Conversely, the bifacial phenomenon in Italy has been re-evaluated (e.g. Villa, 2001; Nicoud, 2013). Other Lower Palaeolithic industries characterized by débitage or small tools are still poorly considered with few exceptions (e.g. Peretto, 1994; Aureli et al., 2012).

The new Valle Giumentina research project (École française de Rome research project 2012-2016; Nicoud et al., 2013, 2014, 2015a,

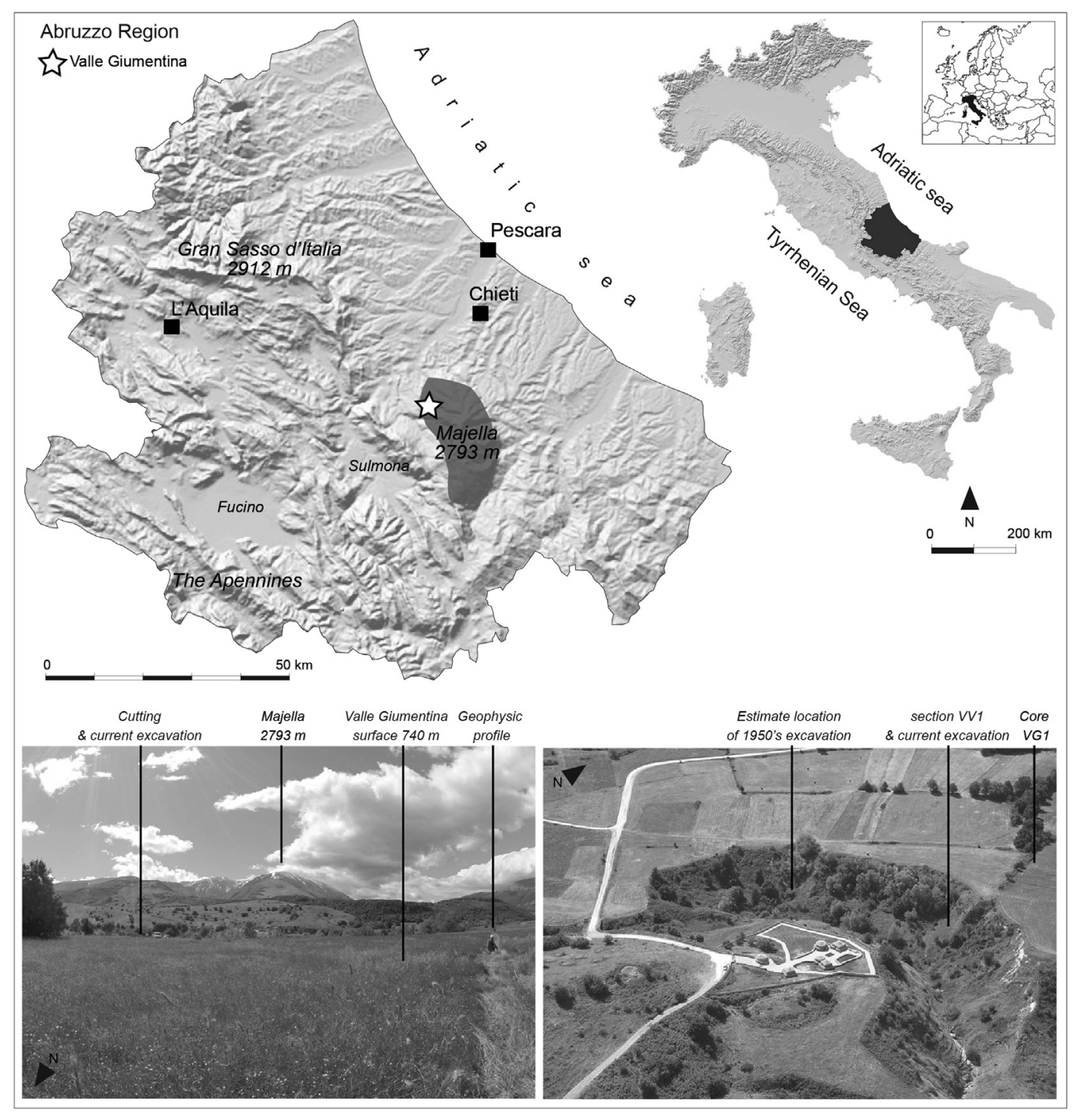

Fig. 1. Location of Valle Giumentina Pleistocene site in the Majella massif (Abruzzo, Italy) and aerial view of Valle Giumentina cutting. 


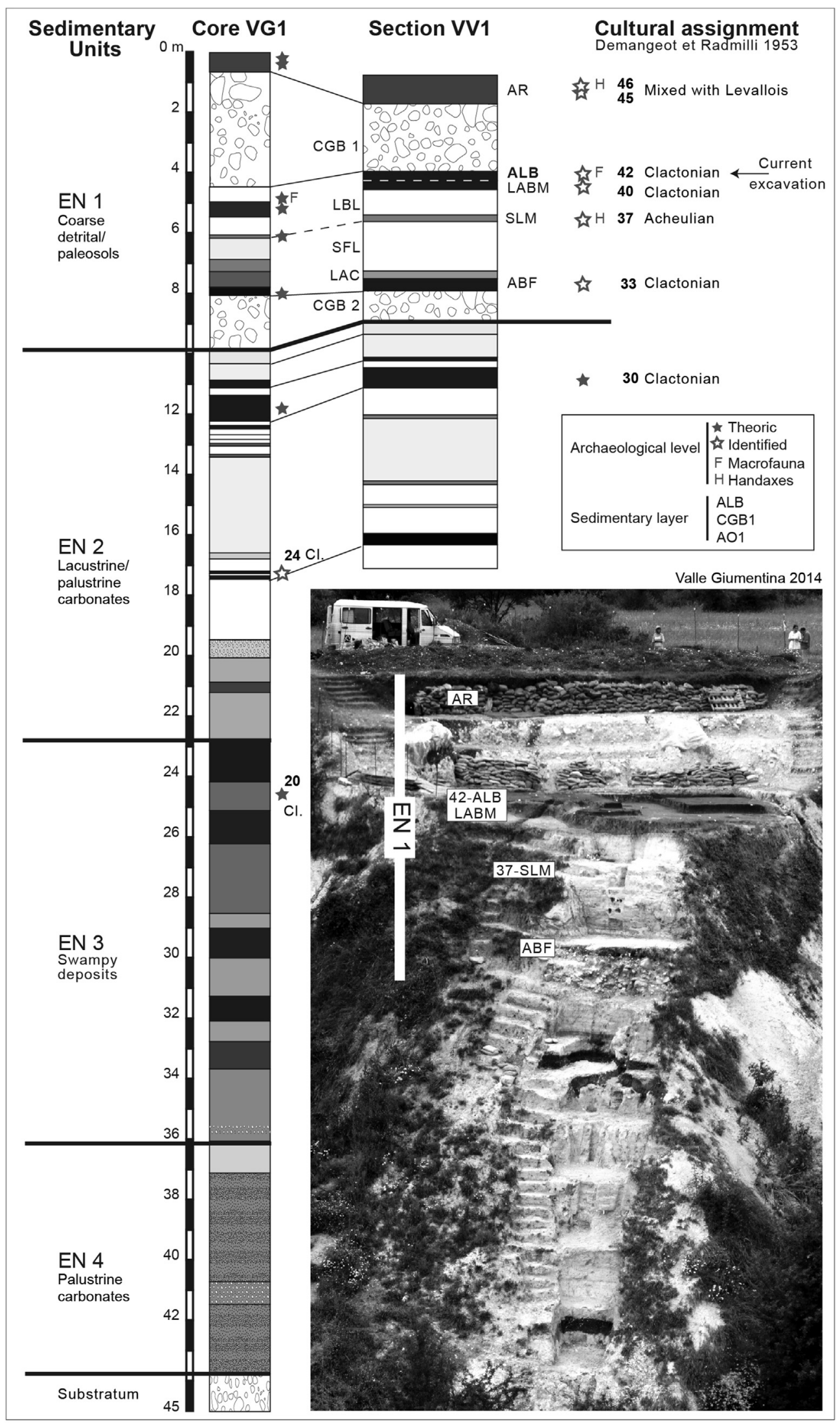

Fig. 2. Schematic stratigraphy of Valle Giumentina from 45 m-long core "VG1" and 17 m-high section "VV1". Photography of the 2014 section "VV1" and excavation of layer 42 -ALB located at $4 \mathrm{~m}$ of depth under the grass field. The sequence is divided in sedimentary units "EN". Stratigraphical explanations are in the text. Stars and numbers (20-46) indicate the archaeological layers discovered during the 1950s and current excavations. 
2015b) provides a good opportunity for addressing these issues of Early Prehistory. Our multidisciplinary approach aims at building a robust and accurate chronological framework as well as understanding the paleoenvironmental context and natures of the nine human occupations preserved in this exceptional sequence. We will present below the studies in progress and the preliminary multidisciplinary results from layer "42-ALB" located between $3.80 \mathrm{~m}$ and $4.30 \mathrm{~m}$ depth (Fig. 3). These results will be then discussed in terms of Prehistoric land-use and economic behaviours. Thanks to a renewed methodology in lithic studies (lithic technology and techno-functional analysis), more than sixty years after Radmilli's work we are now able for the first time to define the technical features hidden under the Clactonian label at Valle Giumentina. As level 42-ALB is the last archaeological level lying before the occurrence of Levallois tradition at Valle Giumentina, we will also discuss the variability of Middle Pleistocene human behaviours close to the onset of the Middle Palaeolithic.

\section{Materials and methods}

\subsection{Regional setting and history of research}

Valle Giumentina is located at $740 \mathrm{~m}$ in the Majella massif which peaks at $2793 \mathrm{~m}$. The basement of the valley is composed of Early Cretaceous-Miocene limestone. The site is located $35 \mathrm{~km}$ from the Adriatic Sea and the city of Pescara. The hilly piedmont and the coastal plain landscapes are carved into the Early Pliocene-
Quaternary marine deposits (Bigi et al., 1996). Here the main rivers flow at $90^{\circ}$ to the coast, such as the Pescara River separating Majella and Grand Sasso massifs. The Majella limestones contain many flint beds. Palaeolithic tools have been discovered up to more than $2000 \mathrm{~m}$ asl (Radmilli, 1999).

The 1953-54 archaeological excavations led by the Italian archaeologist A.M. Radmilli and French geologist J. Demangeot revealed nine archaeological layers with thousands of lithic remains. The work done by these researchers highlighted the frequentation of the Apennines mountainous reliefs by Neandertal and/or pre-Neandertal groups. On the base of lithostratigraphy and because of no other dating methods existing at the time, they assigned the archaeological levels to the Riss and Würm. The occupations were distinguished by A.M. Radmilli in three distinct cultures: Acheulian, Clactonian and Levalloisian, according to the presence of bifaces (level 37), of tools on thick flakes (levels 20, 24, 30, 33 and 42; Fig. 2) and of Levallois flakes and scrapers in the upper levels (45 and 46). Technical studies of recent decades clarified the complexity of Lower and Middle Palaeolithic series and thus the consistency of the cultural groups based only on typological criteria. They are often obsolete or objects of sharp debate (e.g. about Valle Giumentina: Bietti and Castorina, 1992).

\subsection{Multidisciplinary approach: fieldwork, samples and analysis}

Pluridisciplinary researches return at Valle Giumentina for a five-year program founded by the École française de Rome
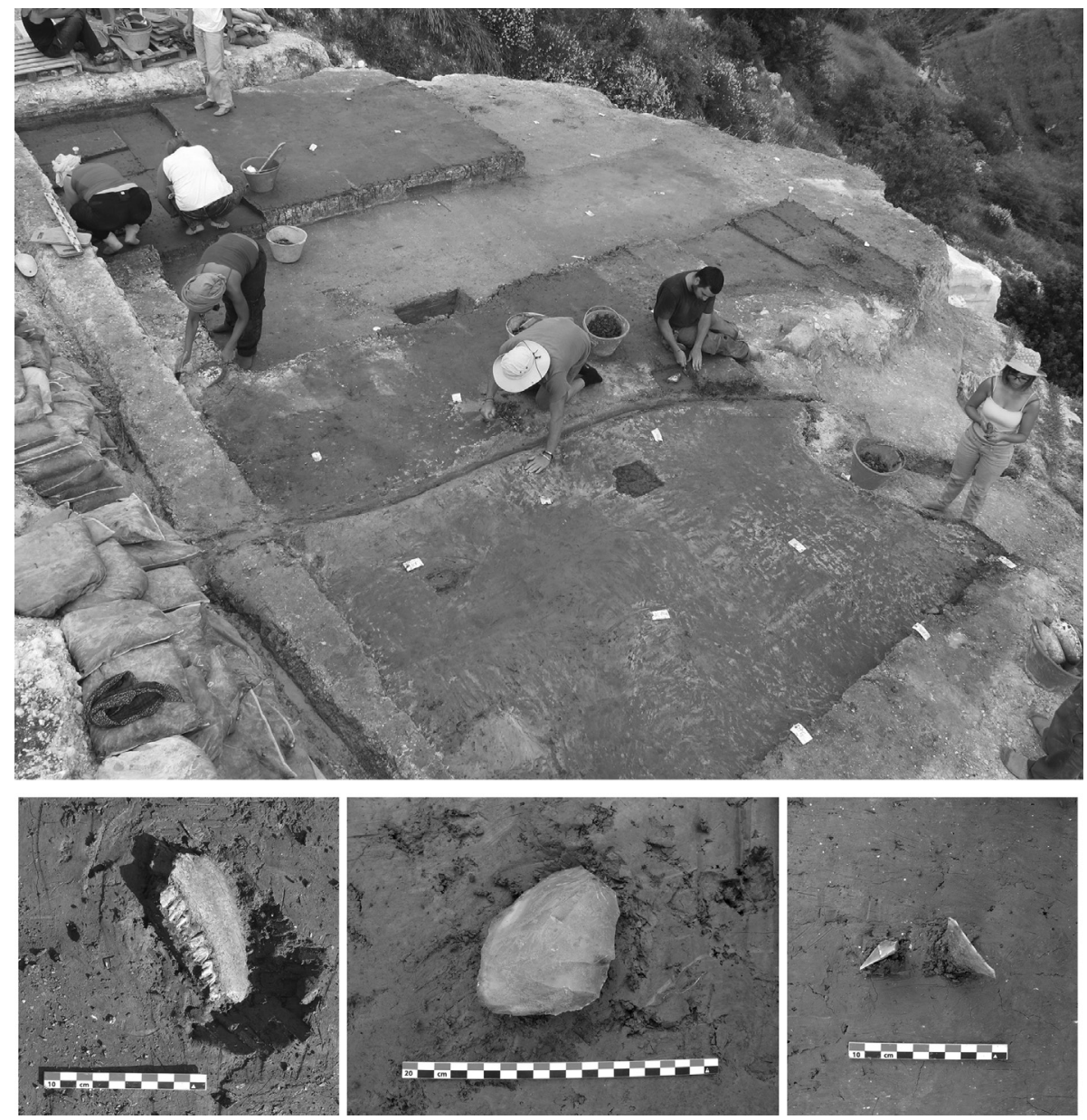

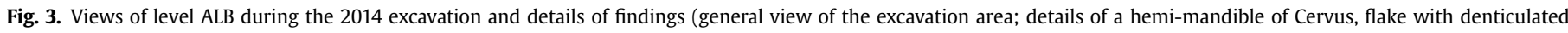
cutting-edge $n^{\circ} 464$, two flakes in vertical position within the clay). 
(2012-2016), in collaboration with the italian Soprintendenza per i beni archeologici dell'Abruzzo. The core of our study is based on a $45 \mathrm{~m}$ borehole named "VG1" drilled through the Quaternary deposits of Valle Giumentina, a 17 m-long section "VV1" excavated along the incision and a geophysical profiles by electric resistivity covering the entire valley.

Geological, geomorphological and chronostratigraphic investigations as well as paleoenvironmental studies (malacology, palynology) and geochronological analyses $\left({ }^{40} \mathrm{Ar} /{ }^{39} \mathrm{Ar}\right.$, OSL, ESR) are in progress. Overall, 240 sedimentary samples from core VG1 and section VV1 are currently analysed (grain size analysis, geochemistry: calcimetry $\mathrm{CaCO} 3$ and organic carbon TOC). Magnetic susceptibility measurements were done every centimetre. One hundred thin sections of undisturbed sediments (size $6 \mathrm{~cm} \times 9 \mathrm{~cm}$ ) will allow detailed micromorphological analysis. Five sedimentological samples for dating by optically stimulated luminescence (OSL on profile VV1) are still under treatment. Eight samples of tephras or volcanic-rich levels from profiles VV1 and VG1 will be studied. Three direct volcanic fall-out samples will be dated by laser single crystal ${ }^{40} \mathrm{Ar} /{ }^{39} \mathrm{Ar}$. Based on our preliminary sedimentary and lithostratigraphic study, where are able to correlate with confidence our new excavation with the historical sequence and archeological layers (Villa et al., 2015).

A total of 300 samples for pollen analysis was collected from core VG1 every $10 \mathrm{~cm}$, within layers with favourable texture (clays and silts). Layer 42-ALB did not preserve pollen. We used malacological study to rebuild the paleobiocenosis during the human occupations. For that purpose, we sampled section VV1 every $10-15 \mathrm{~cm}$ depending on the layer thickness with a constant volume of $10 \mathrm{~L}$ ( 56 samples total). Although most of the analyses are still in progress, the first data on the level 42-ALB already has provided crucial information concerning the paleoenvironnemental context during the human occupation.

The upper layer assigned to the Clactonian by Radmilli named $42-A L B$ is currently manually excavated over $48 \mathrm{~m}^{2}$. Layer $42-A L B$ is $40 \mathrm{~cm}$ thick. Because of the layer's homogeneity, $5 \mathrm{~cm}$ thick artificial cuttings were followed during the excavation. Sieving tests were done to evaluate the presence of very small vestiges. A total of 223 lithic artefacts have been discovered, including 28 retouched items (Table 1). A total of 32 fauna remains have been discovered, but because of the alteration only six specimens were determined both anatomically and taxonomically.

Table 1

Typotechnical features of Valle Giumentina flint lithic series 42-ALB 2012-14.

\begin{tabular}{lr} 
Unretouched blanks & $\mathbf{1 9 5}$ \\
Cores & 3 \\
Flakes and fragments & 183 \\
$\quad$ of which flakes & 49 \\
of which small flakes $<20 \mathrm{~mm}$ & 134 \\
Undefined fragments & 7 \\
Raw material block & 1 \\
Calcareous pebble & 1 \\
Retouched blanks & $\mathbf{2 8}$ \\
Flakes and fragments & 27 \\
$\quad$ of which flakes & 23 \\
$\quad$ of which small flakes $<20$ mm & 4 \\
Core (probably transformed during use) & 1 \\
Total & $\mathbf{2 2 3}$ \\
\hline
\end{tabular}

\subsection{Lithic study methods: structural analysis}

In this paper, we present the results of the study of the artefacts from the recently excavated level 42-ALB obtained by using a technological and structural approach. The tools and the blanks, both being the objectives of production, are precisely described. The transformative parts corresponding to different types of cutting-edges ("contacts transformatifs de type tranchant" sensu Lepot, 1993) and the general volume of the artefacts are presented according to a techno-functional analysis (Lepot, 1993; Soriano, 2000; Boëda, 2001, 2013), including a preliminary use-wear analysis of 35 objects from the 2013 campaign. The objects have been analysed in order to define their overall preservation status and potential in terms of functional (use wear) analysis. The objects have been examined applying both a low and high power approach (Keeley, 1980; Rots, 2010; Van Gijn, 2010). The former was performed with a stereomicroscope Nikon SMZ in reflected light with $10 \times$ oculars, $0.5 \times$ objective and range of magnification from $0.75 \times$ to $7.5 \times$, taking into consideration the possible edge damage present on the tool's edge. A metallographic microscope Nikon Elite in reflected light with oculars $10 \times$ and objectives $10 \times, 20 \times$ and $50 \times$ was used to analyse the micro use wear (polishes, abrasions and striations) present on the tools' edges.

The techno-functional analysis focuses on the modalities of construction of tools and toolkits, with aim of showing the relationships between the blank production stage and the retouch stage. It thus defines the final objectives of the production, both from technological and functional points of view (Lepot, 1993; Soriano, 2000; Boëda, 2001, 2013). We also determined methods and concept of production through technological study of flakes and cores. This integration of technical approaches allows us to cast light on both the activities done on the site and the position of this industry in terms of technical evolution (technogenetic approach sensu Boëda, 2013).

\section{Results}

\subsection{Lithostratigraphical position and paleoenvironmental setting of level $42-A L B$}

Since 2012, the first stratigraphic examination of the Valle Giumentina exposure and core sections made possible the correlation between our field observations with those established sixty years before by Radmilli and Demangeot. Four major sedimentary groups have been defined from the $45 \mathrm{~m}$ VG1 core and the $17 \mathrm{~m}$ VV1 section. They characterize the evolution of the paleolandscape as well as paleoenvironnemental conditions (Villa et al., 2015; Fig. 2). After summarising the whole stratigraphic record, we will focus on the last sedimentary unit EN1, that includes the archaeological level 42-ALB.

The oldest unit EN4 of Valle Giumentina corresponds to the establishment and the early stages of a lake environment. Then, the lake dried and a first soil formed, probably during a warmer and/or drier period. This was followed by the return of wet conditions in EN3. A shallow swamp formed within a vegetated environment. During the first part of EN3, three volcanic ashes layers were found in the organic clay sediment. The second part is characterised by increasing fine detrital input from the basin' slopes. The sector then underwent a new episode of immersion with the establishment of a marshy environment under temperate climatic conditions that tended to deteriorate. In EN2, a wetland environment appeared again. A deep-water lake formed. At the end of EN2, the lake disappeared gradually, replaced by a marsh evolving to a terrestrial environment with the occurrence of pedogenesis. This evolution coincided with the deposition of new volcanic ash fallout.

EN1 is marked by coarse sediments. EN1 includes the archaeological layer 42-ALB and 10 other layers labelled from CGB2 at the bottom to AR at the top. Very coarse grained and thick layers ( $>1 \mathrm{~m}$ ) 
occur at the bottom and the top of EN1, each including chaotic flint gravel and limestone blocks (AR, CGB1 and CGB2). Between these two episodes, the detrital input appears more moderate, represented by finer and bedded deposits.

These sandy-loam units (sand fraction: 20-50\%) are usually carbonated $\left(\mathrm{CaCO}_{3}>40 \%\right)$ : ALB, LABM, LBL, SLM, SSG, SFL, LAC and ABF. LBL, SSG, SFL and LAC with light colours (10YR 7/1) are formed by packed, bedded, and sorted detrital particles. These characters suggest limited fluvial flows and therefore a low energy regime. These layers are made of micritic concretions (80-100\% $\left.\mathrm{CaCO}_{3}\right)$. In unit LAC, these beds appear strongly deformed by convolution. The two upper layered units LBL and SFL are interbedded by the SLM unit with molluscan remains. In thin sections, detrital carbonated particles are mixed with fine organic fragments. Diffuse ferric impregnative pedofeatures also occur.

These fluvial units occur between two phases of environment stability represented by units ALB-LABM and ABF, during which the detrital inputs strongly decreased. These dark brown (10YR 5/4) sediments with low organic matter (TOC: $<0.5 \%$ ), yield detrital calcite particles associated with anorthic nodules of soil material (pedorelicts) and reworked clay coating, both indicating colluvium. However, they are also altered and bioturbated according to micromorphology observations. The latter show in-situ pedofeatures, such as ferric impregnations and laminated argillans located within bioporosities describing soil formation processes. These observations agreed with the mollusc fauna analyses from the ALB layers, which contains the archaeological level, describing a terrestrial landscape with open and dry conditions.

\subsection{Faunal remains}

These are all remains of the Red Deer, Cervus elaphus, and likely of the same individual (as shown by two refitting of right and left cannon bones). The wear stages of the cheek teeth of a right mandible indicate an adult over 3 years old. Scarce human-derived modifications were observed. They include percussion flaking but also striae and chopping evidence, detected on a thoracic vertebral spine. On this latter remain, the caudal articular surfaces have been

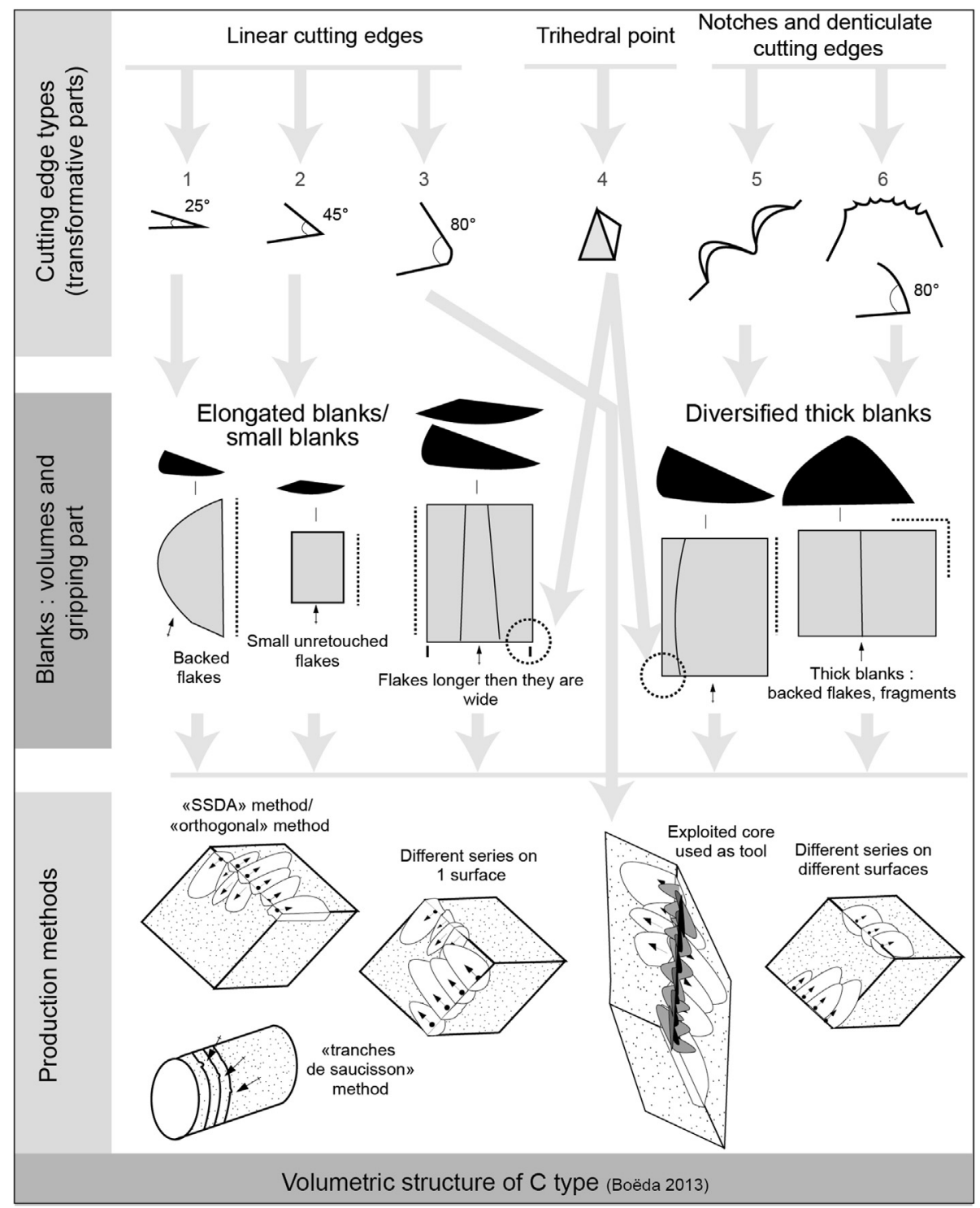

Fig. 4. Overview of techno-functional characteristics of tool construction at Valle Giumentina layer 42-ALB. 
chopped off by a blow oblique to the axis of the spinal process. On the right hand side, the specimen shows a set of parallel striae, oriented obliquely as the chopping plane. The spinal process is also weathered. Its apex is broken off and the fracture patterns suggest dry bone fracture. The right face of the specimen, altered by the striae, is also affected by weak weathering, whereas the cranial articular surfaces appear strongly weathered. In contrast to its right side, the left side of the specimen is not weathered, but altered by humic corrosion and root etching. These lines of evidence indicate this remain was defleshed by humans and dumped, and then lay on the substratum with its right hand side exposed for a while before its final burial.

The fauna sample also comprises three remains of small mammals, two lower incisors, and a fragmental left mandible. The small mammal left jawbone belongs to the Common Vole, Microtus arvalis. It preserves the incisor together with $\mathrm{m} 1$ and $\mathrm{m} 2$. The Common Vole inhabits steppes and dry meadows, but also open cultivated agricultural land such as short meadows, grain fields, and grazed pastures. It can live in climatic conditions cooler than today's.

\subsection{Lithic series}

\subsubsection{Lithic series conservation, composition and raw material}

The lithic industry is well-preserved. Edges are sharp and fresh, and some pieces wear a slight patina. At a micro scale, most of the objects are characterised by an overall good state of preservation. Even though patina or other types of alteration are not common within the sample, there are several cases of patinated and mechanically altered implements. The high degree of preservation allows analysing most of the edge damage and the micro use wear (Figs. 5-7). Edge damage usually appears both under micro fracture clusters located on specific edges, and as well-developed fracture sequences along the edge. Edge rounding is not so common, probably due to the composition of the flint itself. It appears highly resistant and hard, which does not allow the margin to develop a high degree of rounding, either from use or for post-depositional agents. Micro use wear is present as well on the artefacts. Polishes are well developed on most.

All the blanks come from a flake production system (débitage). No shaping production (façonnage) is attested in this layer. Remains

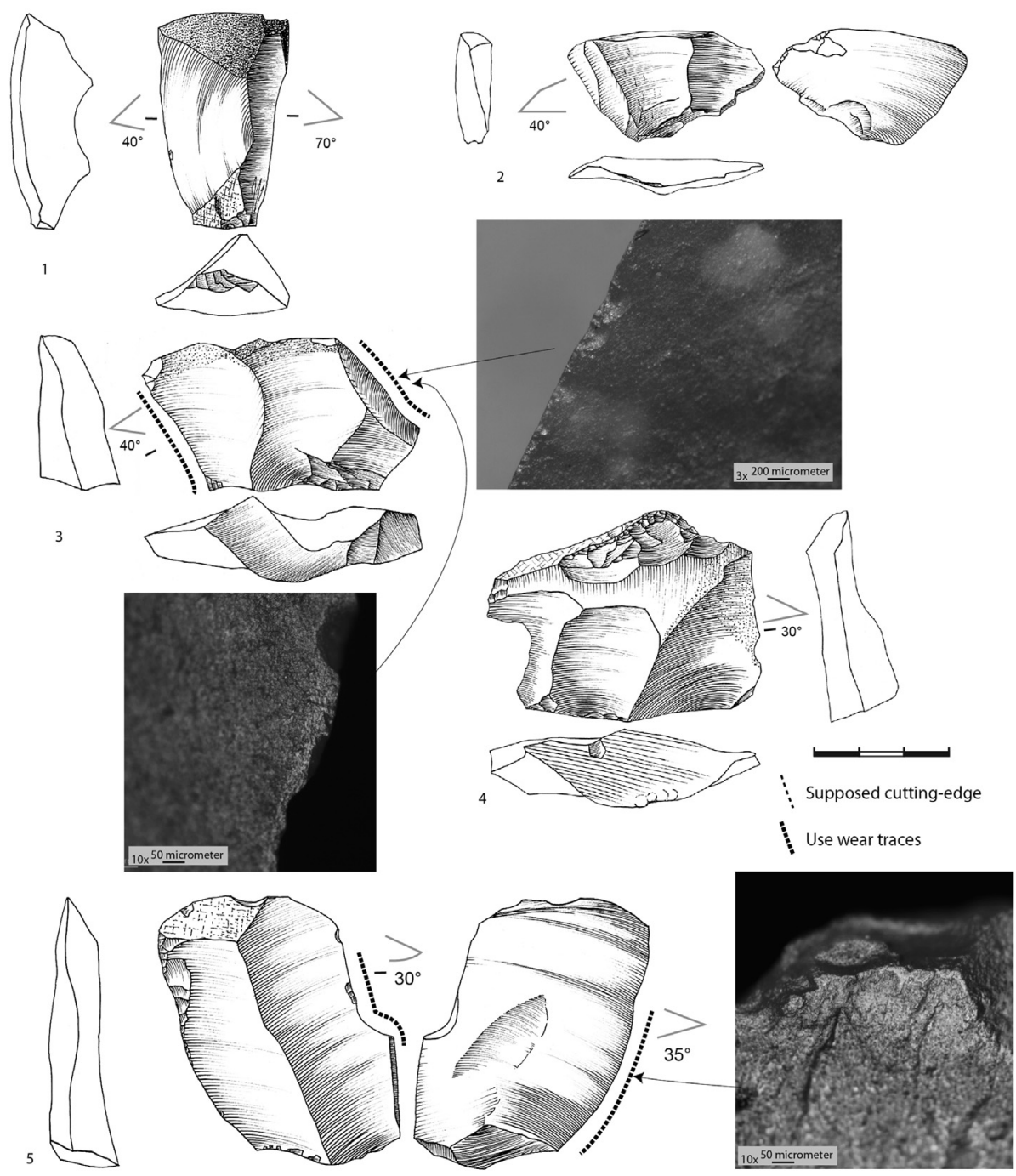

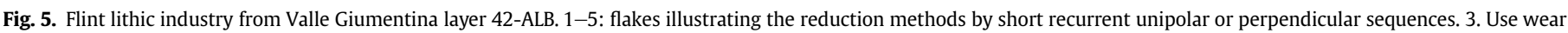

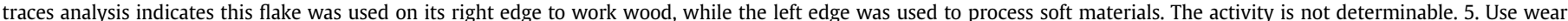

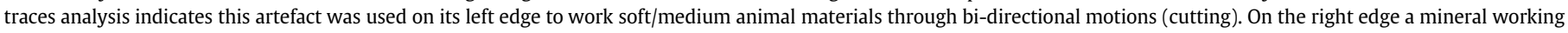
related polish is present probably due to a scraping of the edge on a stone to dull it in order to favour the tool's prehension ( $n^{\circ}$ ref: $8 ; 13 ; 6 ; 62 ; 145$ ). 
correspond to various stages of the production chaîne opératoire, mostly the last ones as showed by the high number of tools $(\mathrm{n}=28)$, whereas cores are rare $(\mathrm{n}=4$; Table 1$)$. The raw material is made of many varieties of flint: grain size, quality, and volumes are different. Its availability can be local or at several kilometres distance in a mountainous environment. As the study is preliminary, we cannot present any petrographic data or precise procurement data. The variability of raw materials and the different chaînes opératoires stages suggest a strong space and time fragmentation of the lithic production. Some refits between remains help to indicate that at least some production stages have been made on the spot. They also ensure limited post-depositional disturbances.

\subsubsection{Techno-functional objectives}

Tools belong to the typological families of scrapers (lateral or distal), of back knives, of notches and of denticulates. Six different types of cutting edges ("contacts transformatifs de type tranchants", Lepot, 1993) were identified. They belong to three technofunctional categories as shown in Fig. 4. Each cutting-edge type is defined by the following criteria: the morphology of the surfaces (convex, flat or concave) that create the edge, the angle value before and after retouch, and the delineation of the edge. These cuttingedges are made out of specific volumes.

The first category of edges includes linear cutting-edges, with a bi-flat or flat-convex edge section. Edges angles are more or less sharp $\left(25^{\circ}-60^{\circ}\right.$; Figs. 5 and 6$)$. Another edge type is characterized by a long blunted edge with an $80^{\circ}$ angle. This specific edge was noted on a core, which has been reused, certainly as a very robust tool in launched percussion. Retouch is sometimes made by several rows of removals with a scalar profile (Figs. $6 n^{\circ} 3$ and $8 n^{\circ} 1$ ). It can also be very partial (Fig. $7 n^{\circ} 2$ ). However, the intensive retouch is not associated with any specific blanks. The second category groups some trihedral points as the one existing at the intersection between the butt, the ventral and the upper surface of a flake. It can also be created thanks to voluntary fractures, and in this case its functional purpose is highlighted by some small esquillements (Fig. $8 \mathrm{n}^{\circ} 2$ ). The third category includes notches and denticulate cutting-edges (Fig. 9). Notches are sometimes created by several rows of removals which reinforce the flat-concave section. A little prominent transformative part with flat-convex section happens at
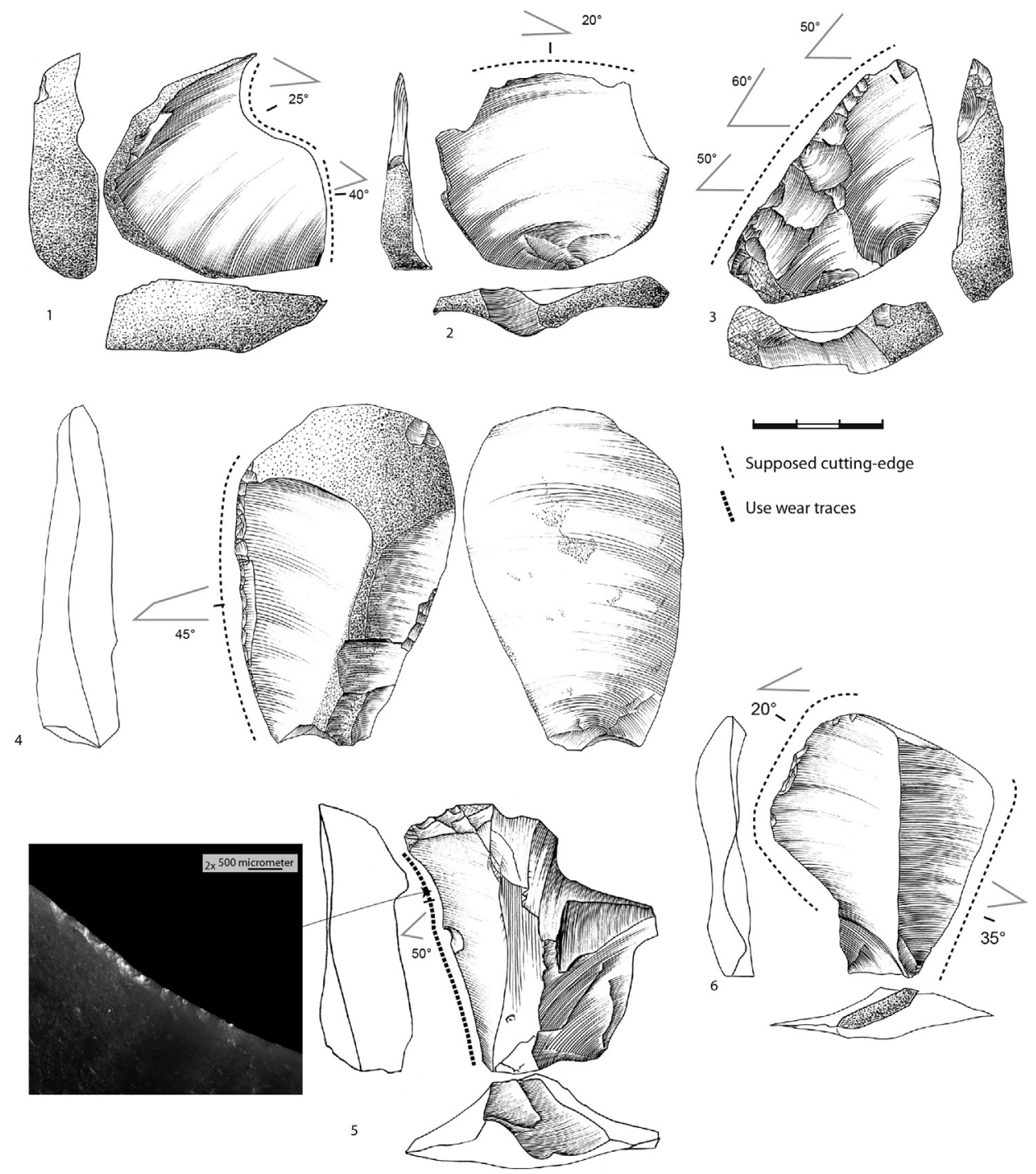

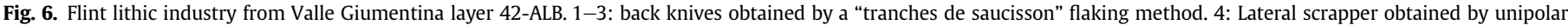

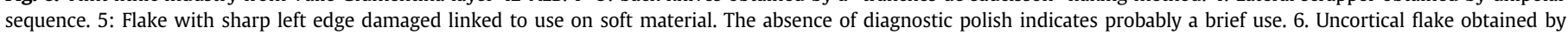
unipolar sequence ( $\mathrm{n}^{\circ}$ ref: $510 ; 412 ; 430 ; 488 ; 381 ; 543$ ). 
the intersection of two notches. Denticulate edges are flat-convex in section, and their angles vary between $45^{\circ}$ and $80^{\circ} / 90^{\circ}$.

These various cutting-edges types are made on different kinds of blanks, mostly on flakes or fractured flakes but also on cores. Linear edges with bi-flat or flat-convex sections are built mostly on elongated blanks. These are flakes, longer than they are wide and conversely, and also backed knifes. The cutting-edge is always on the longest side of the flake. Small not-elongated flakes are also noted. Notches and denticulate edges are mostly built on thick blanks of varied volumetric structures. They are both elongated and not, cortical or débordant backed flakes and fractured flakes (Fig. 8 $\mathrm{n}^{\circ} 2$ ). Notches and denticulate edges are localised on the longest or on the shortest side of the blank. Blank lengths are between $1.5 \mathrm{~cm}$ and $12 \mathrm{~cm}$. Many unretouched small and thin flakes as well as backed flakes have the same morphological characteristics as retouched blanks. The presence of a back on the opposite or the adjacent side of the cutting-edge is frequent (Fig. 6). This back can be natural, cortical, or resulting from a former flaking secant surface (débordant flake). Backs can be also represented by fractured surfaces. Most of the flakes' butts are large because of the mode of percussion. The butt is often in continuity with a lateral back or is large enough to be the gripping part.

The use-wear analysis confirms the techno-morphological recognitions. Overall, use wear is present both on whole and fractured implements. This latter category includes mostly small flakes. Although micro scarring caused by mechanical fracture is characterised by similar features as the ones generated by use, there are several examples of fractured edges exhibiting edge damage, possibly caused by use.

\subsubsection{Technique, methods and concept of production}

The percussion technique is invariably the launched percussion of a hard hammer in the internal part of the block. This gesture classically produces thick flakes with large and inclined butts but it also creates planar ventral surfaces with no prominent bulbs and sometimes an arris on the bulb. Series of incipient cones around the impact point indicate the repetition of the stroke.

The production methods are illustrated by core structures and previous removals direction on flakes (Fig. 10). Flakes were obtained by short unipolar series on secant adjacent flaking surfaces. This sequences are unipolar, unipolar convergent or perpendicular, without preliminary preparation of the striking platform or the flaking surface.

Cores and flakes show that the first stage of production is only an accurate selection of surfaces with suitable volumetric characteristics. Then, reduction takes place in one or more surfaces on the core, by a short series of removals. The sequence of gestures corresponds to different flaking methods: a "tranches de saucisson" method (Turq, 1989), an alternating surfaces method resembling the SSDA method (Forestier, 1993) and an orthogonal flaking (sensu Ashton et al., 1994). A secondary reduction is also noted, similar to flake production at Les Tares site (Geneste et al., 1997; Turq, 2000).

All these methods refer to a single concept of core volumetric structure. It can be described as " $\mathrm{C}$ type", belonging to an "abstract" production concept (Boëda, 2013). In this system, block selection is a crucial phase. One or more under-volumes ("useful volumes") of the block are exploited independently. Striking platforms are natural or opened by a first flake. These useful volumes are made of one or more flaking surfaces which have naturally adequate
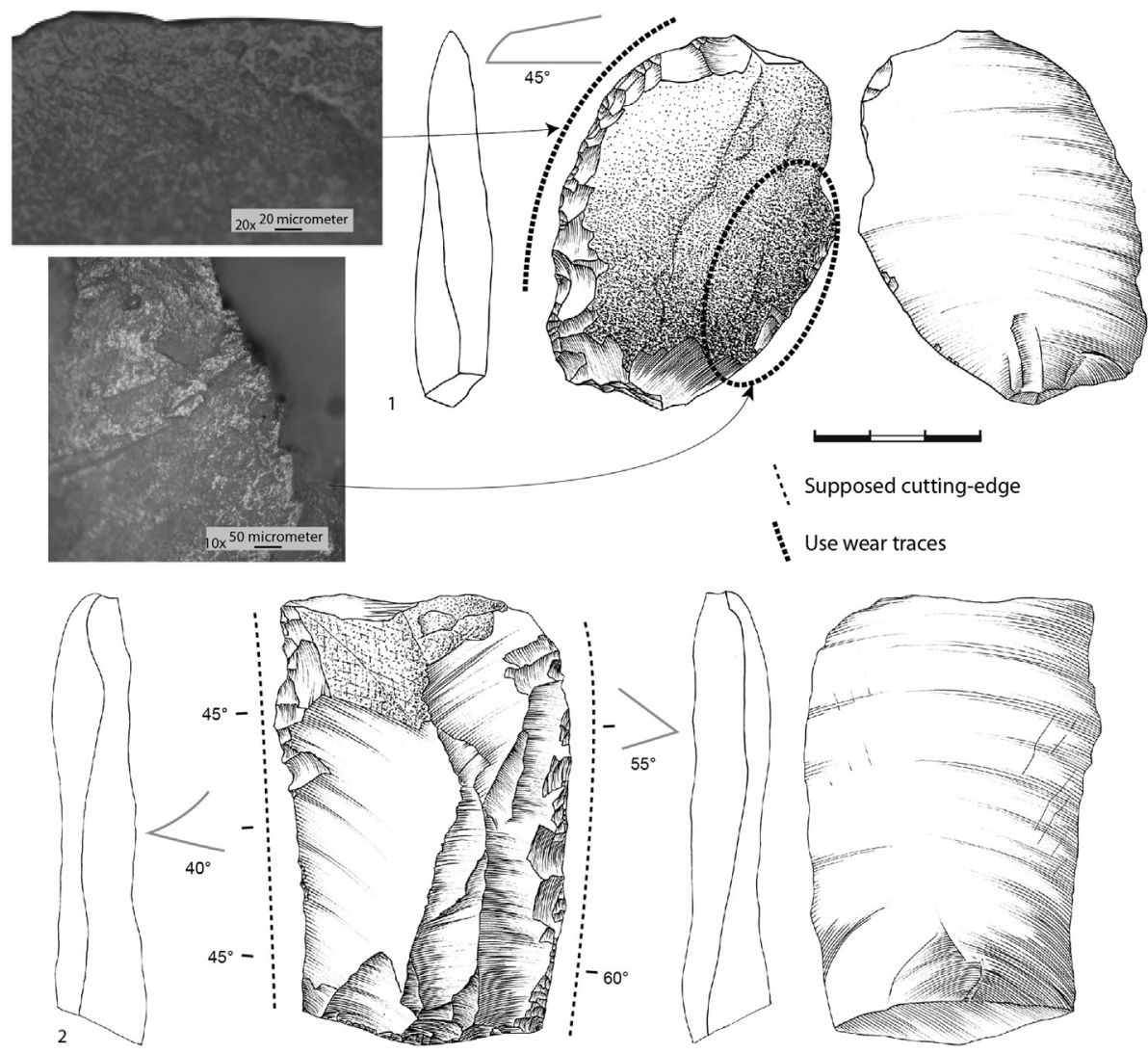

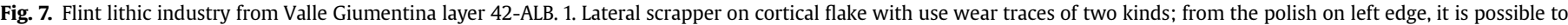

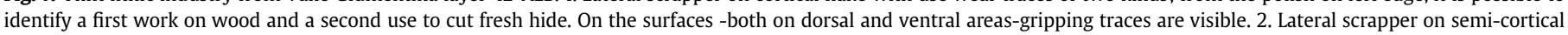
flake ( $n^{\circ}$ ref: $87 ; 548$ ). 
convexities, allowing short series of removals without any successive preparation. Thus, each core can produce various flakes according to the desired blanks and the initial morphology of the flaking surface. In this system, the presence of backs is frequent. The flaking continuity and the production of large flakes result from the use of former arris to guide the stroke wave.

\section{Discussion}

Until we obtain radiometric dating results, the age of this Palaeolithic settlement is still unknown. The 42-ALB paleosol is in the upper part of the very thick depositional sequence of Valle Giumentina and occurs before the last episode of coarse deposition. The low faunal spectrum (Cervus elaphus, Microtus arvalis) does not provide much paleoclimatic and environmental indications. However, sedimentological and malacological studies indicate a slight climatic improvement that occurred during an overall cold climatic context (glacial period). Human occupations in Valle Giumentina took place far from the paleolake, or when the lake was dry.

The flake industry of Valle Giumentina level 42-ALB was described as Clactonian in 1953 by Radmilli, but this cultural group is now regarded as obsolete, including in Britain, its homeland (Ashton et al., 1994). We usually describe this industry by negative criteria because it suggests simple production, even opportunistic: there is no core preparation, nor convexities making during flaking, and it is not Levallois. At first glance, this kind of industry appears as a common pool of Lower and Middle European Palaeolithic. The techno-functional and technological study emphasises the functional objectives, the many methods to obtain the tools under a unique concept of production.

Combining the data from sedimentological and malacological study, spatial organization, lithic industry and faunal remains analysis gives taphonomic indications on the processes that characterise the archaeological level. Valle Giumentina is a well preserved open-air site with a low density of remains. The archaeological level 42-ALB is associated with a paleosol. The lithic and faunal refits as well as the weak traces of weathering on flint artefacts indicate limited post-depositional disturbances.

According to our first results, the lithic industry shows technological consistency and is essentially made of the last step of the production chaîne opératoire. Many discarded tools occur. In addition, the nature and the low intensity of use-wear traces observed

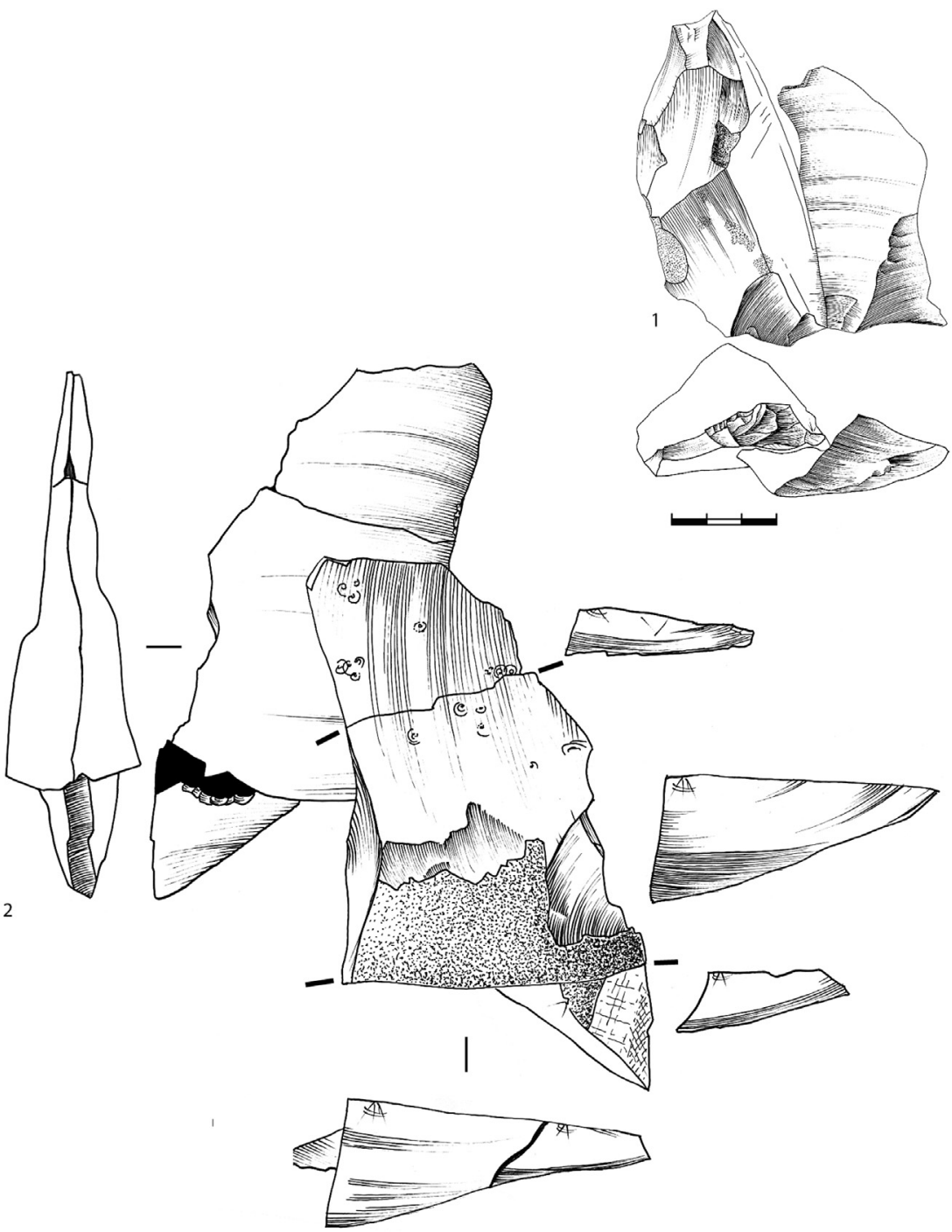

Fig. 8. Flint lithic industry from Valle Giumentina layer 42-ALB. $1-2$ : Refits ( ${ }^{\circ}$ ref: 706/707; 459/462/472). 
on the tools indicate that the 42-ALB excavated area was dedicated to short time butchery activities, during which the tools were briefly used.

This industry recalls many aspects of the Late Middle Palaeolithic site of Le Fond des Blanchards (Yonne, France; Lhomme et al., 2011). An "abstract" production concept occurs there, as well as some similar flaking methods, great variability of blank morphology, and the unsystematic use of the scaled retouch on several rows. In addition, similarly to Valle Giumentina, the scaled retouch creates various types of cutting-edges on different kinds of blanks. Differing from what was first claimed by Radmilli (1965), we think these criteria forbid us to put the Valle Giumentina industry together with the Quina industry stricto sensu as known in Southwestern France mostly during MIS 4. The latter is made of more fixed and rigorous methods, blanks and retouch (Bourguignon, 1997).

The most striking aspect of this industry is the originality of Valle Giumentina industries within the Italian context. This site is quite dissimilar to other Italian Lower and Middle Palaeolithic industries, including the historical Clactonian Italian series. Moreover, Valle Giumentina has been compared to the Clactonian of Sardinia (Palma di Cesnola, 1996; Martini, 1999). This was in particular due to the presence of thick flakes with inclined and large butts and to typological similarities of tools. According to more recent studies, the Sardinian industry has a larger variety of methods and blanks types, as shown by the evidence of laminar cores and flakes (Aureli, 2009).

Our new research on Valle Giumentina also reveals a technical complexity that does not support the Clactonian classical and typological definition. The term could define a technical gesture an internal stroke - and a volumetric structure - "abstract" - more than any cultural reality. The originality of the Valle Giumentina industries was clear since the first research, and we understand now why it was so difficult for Radmilli to describe this industry in the 1950s. He chose to create an original complex: Evolved Clactonian of Valle Giumentina facies. Our technical approach shows the techno-functional variability of this lithic industry. Further comparisons must be made with other Middle Pleistocene sites in Italy
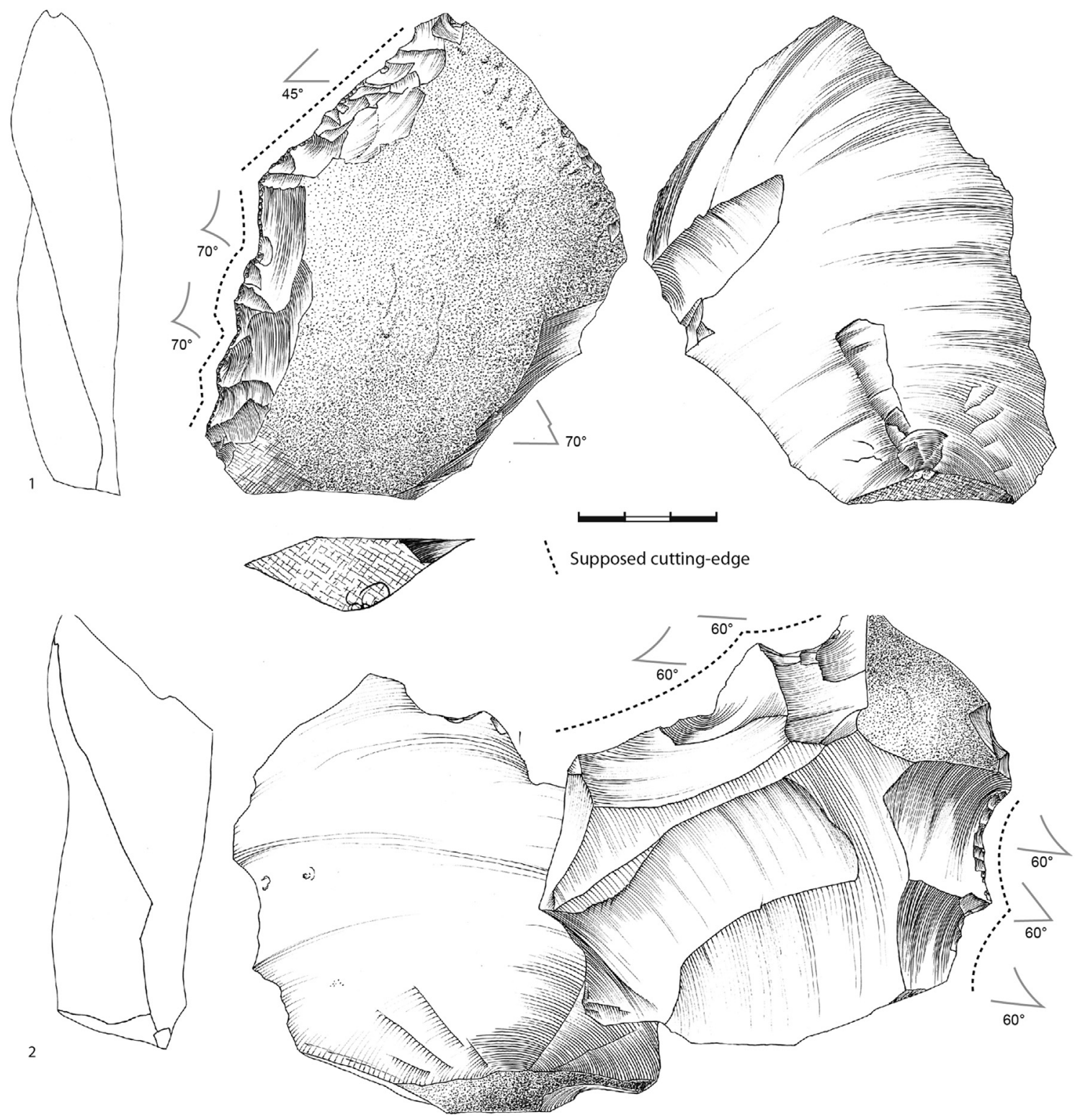

Fig. 9. Flint lithic industry from Valle Giumentina layer 42-ALB. 1-2: Cortical and semi-cortical flakes with (1) denticulate cutting edges and (2) notches (n ${ }^{\circ}$ ref: 464 ; 692 ). 

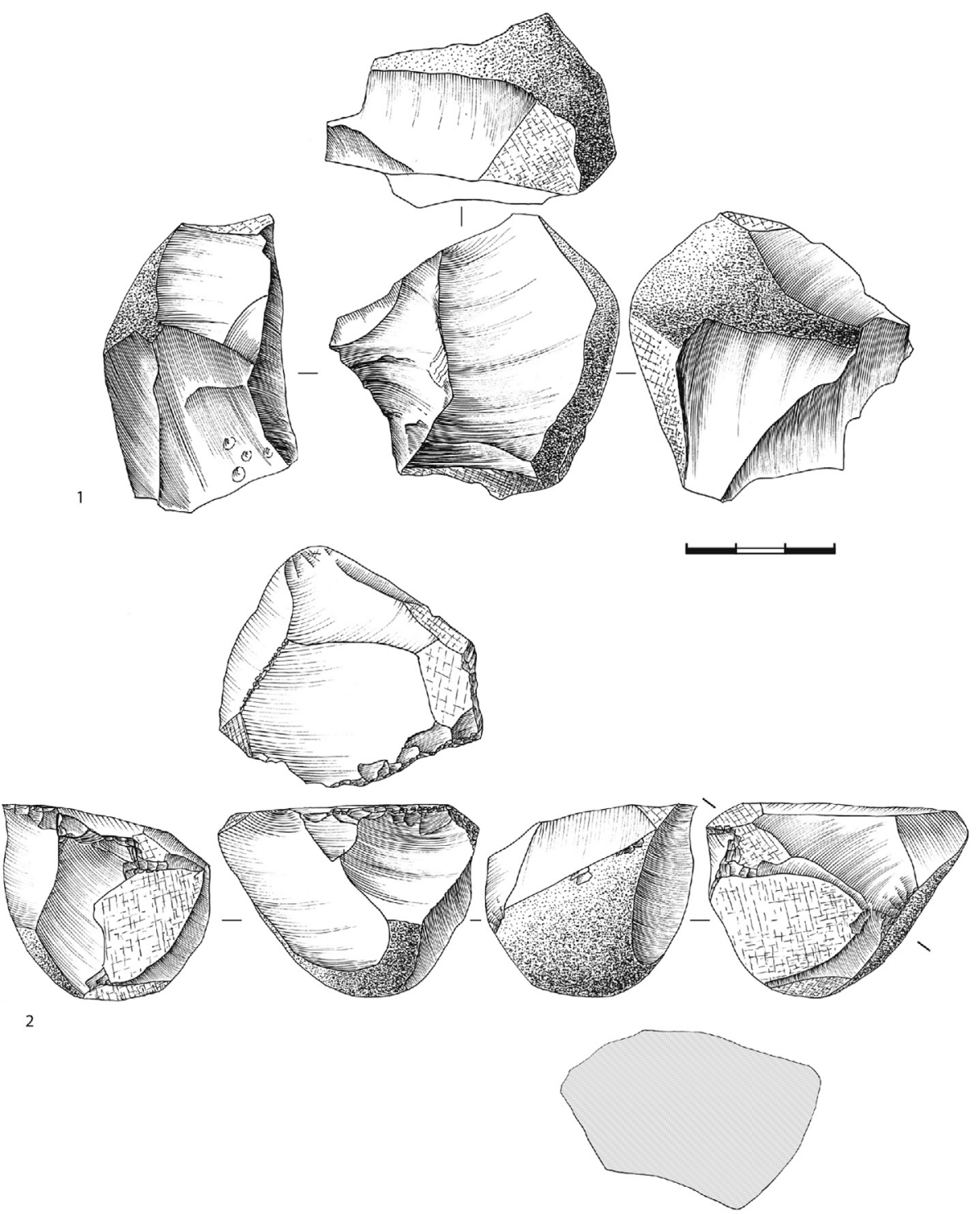

Fig. 10. Flint lithic industry from Valle Giumentina layer 42-ALB: cores ( ${ }^{\circ}$ ref: $\left.144 ; 424\right)$.

such as the adjacent site of Monte Conero in the March region which contains several archaeological levels (Bartolomei et al., 1965). During the Middle Pleistocene, the Italian peninsula shows a great variety of lithic industries whose technical or/and functional relations are not yet completely understood.

\section{Conclusion}

After only two excavation campaigns, this first assessment delivers information on level 42-ALB of Valle Giumentina. The socioeconomic characteristics of the occupation and the functional role of the lithic industry have been partially revealed. This paper also raises the question of the place of the site of Valle Giumentina among Lower and Middle Palaeolithic in Italy and Europe. Many tools that appear to have been used during short time butchery activities were identified thanks to a structural study integrating lithic technology, techno-functional and a preliminary but promising use-wear analysis. In addition, this series shows the fragmentation in time and space of the production chaîne opératoire and demonstrate the territorial mobility of the human groups. Future research on raw materials procurement will help us to comprehend human choices and behaviours. Before comparing these socio-economic results with other European data, much has yet to be done on the very long sequence of Valle Giumentina, in particular with the so-called Acheulian industry. When radiometric dating will be available, it will be possible to highlight the technical and socio-economical changes through time as well as the functional significance of the many occupations of this open-air site. The well preserved archaeological record of Valle Giumentina with nine archaeological levels within a $25 \mathrm{~m}$ thick sequence put it as a key-site to understand better in near future the interactions between changing environments and Middle Pleistocene human societies.

\section{Acknowledgements}

The pluridisciplinary research project at Valle Giumentina is carried on by the École française de Rome and the Soprintendenza per i beni archeologici dell'Abruzzo. It is also supported by the Parco nazionale della Majella and the Fondazione Pescarabruzzo as well as the Cities of Abbateggio and Caramanico Terme in Pescara 
Province, the Archeoclub di Pescara and the Museo delle Genti d'Abruzzo.

\section{References}

Aureli, D., 2009. Lo studio tecnologico dell'insieme litico di Sa Pedrosa Pantallinu (SS): nuove prospettive sul primo popolamento della sardegna (Ph.D. thesis). University of Siena, Italy.

Aureli, D., Contardi, A., Giaccio, B., Modesti, V., Palombo, M.R., Rozzi, R., Sposato, A. Trucco, F., 2012. Straight-tusked elephants in the Middle Pleistocene of northern Latium: preliminary report on the Ficoncella site (Tarquinia, central Italy). Quaternary International 255, 29-35.

Ashton, N.M., McNabb, J., Irving, B., Lewis, S.G., Parfitt, S., 1994. Contemporaneity of Clactonian an Acheulian flint industries at Barnham, Suffolk. Antiquity 68, 585-589.

Bartolomei, G., Broglio, A., Leonardi, P., 1965. Le industrie del Paleolitico inferiore e medio raccolte in situ sul Monte Conero presso Ancona (Marche). Atti X Riunione Scientifica, Istituto Italiano di Preistoria e Protostoria, Florence, pp. 23-40.

Bigi, S., Cantalamessa, G., Centamore, E., Didaskalou, P., Dramis, F., Farabollini, P. Gentili, B., Invernizzi, C., Micarelli, A., Nisio, S., Pambianchi, G., Potetti, M., 1996. La fascia periadriatica marchigiano-abruzzese dal Pliocene medio ai tempi attuali: evoluzione tettonico-sedimentaria e geomorfologica. Studi Geologic Camerti 1995 (1), 37-49.

Bietti, A., Castorina, G., 1992. Clactonian and Acheulean in the Italian Lower Paleolithic: a re-examination of some industries of Valle Giumentina (Pescara Italy). Quaternaria Nova II, 41-59.

Boëda, E, 2001. Détermination des Unités Techno-fonctionnelle des pièces bifaciales provenant de la couche acheuléenne $C^{\prime} 3$ base du site de Barbas I. In: Clicquet, D. (Ed.), Les industries à outils bifaciaux du Paléolithique moyen d'Europe occidentale. ERAUL 98, Liège, pp. 51-75.

Boëda, E., 2013. Techno-logique \& Technologie, une Paléo-histoire des objets lithiques tranchants. @rchéo-éditions, Prigonrieux.

Bourguignon, L., 1997. Le Moustérien de type Quina, nouvelle définition d'une entite technique (Ph.D. thesis). University of Paris X Nanterre, France.

Breuil, H., 1932. Les industries à éclats du paléolithique ancien, I, le Clactonien. Préhistoire 1 (2), 125-190.

Demangeot, J., Radmilli, A.M., 1953. Le gisement quaternaire de la Valle Giumentin (Abruzzes adriatiques), Stratigraphie et Palethnologie. Contributi di Scienze geologiche, supplemento alla Ricerca Scientifica 3, 11-123.

Demangeot, J., Radmilli, A.M., 1966. Le gisement paléolithique de Valle Giumentina (Apennin central) et ses problèmes. Eiszeitalter und Gegenwart 17, 159-299.

Forestier, H., 1993. Le Clactonien : mise en application d'une nouvelle méthode de débitage s'inscrivant dans la variabilité des systèmes de production lithique au Paléolithique ancien. Paléo 5, 53-82.

Geneste, J.-M., Jaubert, J., Lenoir, M., Meignen, L., Turq, A., 1997. Approche technologique des Moustériens Charentiens du sud-ouest de la France et du Languedoc oriental. Paléo 9, 101-142.

Gijn, A. van, 2010. Flint in Focus; Lithic Biographies in the Neolithic and Bronze Age. Sidestone Press, Leiden.

Grifoni, R., Tozzi, C., 2006. L'émergence des identités culturelles au Paléolithique inférieur: le cas de l'Italie. Comptes Rendus Palé 5, 137-148.

Keeley, L.H., 1980. Experimental determination of stone tool uses. In: Butzer, K.W. Freeman, L.G. (Eds.). The University of Chicago Press, Chicago and London.
Lepot, M., 1993. Approche techno-fonctionnelle de l'outillage lithique moustérien: essai de classification des parties actives en termes d'efficacité technique (Master thesis). University of Paris X Nanterre, France.

Lhomme, V., Nicoud, E., Pagli, M., Rocca, R., 2011. The lithic production systems of the Middle Palaeolithic settlement of "le Fond des Blanchards" (Gron-YonneFrance). In: Conard, N.J., Richter, J. (Eds.), Neanderthal Lifeways, Subsistence and Technology, Bonn Conference Series, Vertebrate Paleobiology \& Paleoanthropology, vol. 2. Springer Heidelberg, New York, pp. 121-132.

Martini, F., 1999. Sardegna paleolitica: studi sul più antico popolamento dell'isola. Museo fiorentino di preistoria Paolo Graziosi, Firenze.

Nicoud, E., 2013. Le paradoxe acheuléen. Bibliothèque des Écoles françaises d'Athènes et de Rome 356. Comité des Travaux Historiques et Scientifiques, Rome-Paris, p. 309.

Nicoud, E., Aureli, D., Pagli, M., Agostini, S., Boschian, G., Chaussé, Degeai, J.-P., Fusco, F., Kuzucuoglu, C., Mazza, P., 2013. Valle Giumentina (Abruzzes, Italie). Chronique des activités archéologiques de l'Ecole française de Rome. URL: http://cefr.revues.org/902.

Nicoud, E., Aureli, D., Pagli, M., Agostini, S., Boschian, G., Chaussé, C., Colalelli, U., Degeai, J.-P., Fusco, F., Hernandez, M., Kuzucuoglu, C., Lahaye, C., Lemorini, C. Mazza, P., Mercier, N., Robert, V., Rossi, M.-A., Villa, V., Virmoux, C. Zupancich, A., 2014. Valle Giumentina (Abruzzes, Italie), deuxième mission. Chronique des activités archéologiques de l'École française de Rome. URL: http://cefr.revues.org/1081.

Nicoud, E., Aureli, D., Pagli, M., 2015a. Valle Giumentina (Abruzzes, Italie), troisième mission. Chronique des activités archéologiques de l'École française de Rome. URL: http://cefr.revues.org/1306.

Nicoud, E., Aureli, D., Pagli, M., 2015b. Comportements techniques au Pléistocène moyen en Italie: nouvelles recherches sur l'industrie lithique et le site de Valle Giumentina (Abruzzes). Mélanges de l'Ecole française de Rome-Antiquité 20151. http://mefra.revues.org/2659.

Palma di Cesnola, A., 1996. Le Paléolithique inférieur et moyen en Italie. J. Milon, Grenoble.

Peretto, C., 1994. Le industrie litiche del giacimento paleolitico di Isernia La Pineta, la tipologia, le tracce di utilizzazione, la sperimentazione. Istituto regionale per gli studi storici del Molise «V. Cuoco », Cosmo Iannone, 493 p.

Radmilli, A.M., 1965. Abruzzo Preistorico, il Paleolitico inferiore-medio abruzzese, Florence.

Radmilli, A.M., 1999. Primi uomini in Abruzzo, il Paleolitico inferiore. Museo delle Genti d'Abruzzo, Pescara.

Rots, V., 2010. Prehension and Hafting Traces on Flint Tools: a Methodology. Leuven University Press, Leuven.

Soriano, S., 2000. Outillage bifacial et outillage sur éclat au Paléolithique ancien et moyen: oexistence et interaction (Ph.D. thesis). University of Paris X-Nanterre.

Turq, A. 1989. Approche technologique et économique du faciès Moustérien de type Quina: étude préliminaire. Bulletin de la Société Préhistorique Française 86 (8), 244-256.

Turq, A., 2000. Le Paléolithique inférieur et moyen entre Dordogne et Lot. Paléo supplément 2, Les Eyzies-de-Tayac.

Villa, P., 2001. Early Italy and the colonization of Western Europe. Quaternary International 75, 113-130.

Villa, V., Chaussé, C., Nicoud, E., Aureli, D., Pagli, M., 2015. Valle Giumentina (Abruzzes, Italie); nouvelles observations de la stratigraphie. Mélanges de l'École française de Rome-Antiquité 2015-1. http://mefra.revues.org/2658. 